\title{
DESCRIPTION OF THE FEMALE OF THE MYRMECOPHILOUS MITE ANTENNOPHORUS GOESSWALDI WIŚNIEWSKI ET HIRSCHMANN, 1992 (ACARI: MESOSTIGMATA: ANTENNOPHORIDAE)
}

\author{
Viacheslav A. Trach ${ }^{1,2^{*}}$ and Andrei N. Bobylev ${ }^{3}$ \\ ${ }^{1}$ Odessa I.I. Mechnikov National University, Odessa, Ukraine \\ ${ }^{2}$ Ukrainian I.I. Mechnikov Anti-Plague Research Institute, Odessa, Ukraine \\ ${ }^{3}$ Tyumen State University, Tyumen, Russia \\ *corresponding author; e-mail: vatrach@gmail.com
}

\begin{abstract}
The first description of the female of Antennophorus goesswaldi Wiśniewski et Hirschmann, 1992 (Acari: Mesostigmata: Antennophoridae) associated with the ant Lasius flavus Fabricius, 1781 (Hymenopteta: Formicidae) from Crimea is provided. The family Antennophoridae is recorded in Crimea for the first time.
\end{abstract}

KEY WORDS: Parasitiformes; Trigynaspida; Antennophorina; ants; Formicidae; Lasius flavus; morphology.

DOI: $10.21684 / 0132-8077-2018-26-2-227-235$

\section{INTRODUCTION}

The suborder Trigynaspida comprises about 350 mite species from 27 families that are mostly associated with arthropods in subtropical and tropical habitats (Lindquist et al. 2009; Beaulieu et al. 2011). Four families of Trigynaspida have been recorded from Crimea: Celaenopsidae, Cercomegistidae, Diplogyniidae and Parantennulidae (Khaustov 1997, 1999; Trach 2013; Trach and Khaustov 2017; unpublished data).

The monotypic family Antennophoridae is characterized by a Holarctic distribution and includes ten described species: Antennophorus boveni Wiśniewski et Hirschmann, 1992; A. donisthorpei Wheeler, 1910; A. foreli Wasmann, 1902; A. goesswaldi Wiśniewski et Hirschmann, 1992; A. grandis Berlese, 1904; A. krantzi Wiśniewski et Hirschmann, 1992; A. pavani Wiśniewski et Hirschmann, 1992; A. pubescens Wasmann, 1899; A. uhlmanni Haller, 1877 ; and $A$. wassmanni Wheeler, 1910 (Haller 1877; Wasmann 1899, 1902; Berlese 1904; Wheeler 1910; Krantz 1970; Wiśniewski and Hirschmann 1992).

Mites of the genus Antennophorus Haller, 1877 are closely associated with ants of the genus Lasius Fabricius, 1804 (Hymenoptera: Formicidae). In Europe, their hosts are Lasius alienus (Förster); L. flavus Fabricius; L. fuliginosus (Latreille); L. mixtus (Nylander); L. niger (Linnaeus); L. umbratus (Nylander) (Janet 1897; Wasmann 1902; Berlese 1904; Karawaiew 1905a, 1905b; Wiśniewski and Hirschmann 1992).

The mites position themselves under the ant's head and induce themselves to regurgitate a drop of fluid by stroking the ant's mouthparts with their hypertrophied pair of front legs (Franks et al. 1991; Lindquist et al. 2009).

During the study of mites associated with insects, Alexander A. Khaustov found specimens of the genus Antennophorus on Lasius flavus in Crimea. Later, these mites were identified as Antennophorus goesswaldi Wiśniewski et Hirschmann, 1992 by the senior author. This species was described on the base of one male specimen from the ant Lasius flavus; it is known only from the type locality-Poland (Wiśniewski and Hirschmann 1992). The family Antennophoridae is reported from Crimea for the first time.

The purpose of this paper is to describe a female of Antennophorus goesswaldi.

\section{MATERIAL AND METHODS}

The ants were sampled with the help of an aspirator and placed into vials containing 96\% ethanol. Mites from the alcohol sediments were extracted and mounted in Hoyer's medium for the purposes of light-microscopy. The morphology of mites was studied with the aid of an Axioskop 40 microscope (Carl Zeiss) as well as a compound microscope, a Mikmed-1 (Lomo), equipped with a binocular head AU-12, an ocular micrometer AM9-2 and a digital camera DCM900. SEM micrographs were taken with the aid of a JSM-6510LV SEM microscope (JEOL). The morphological terminology generally follows Evans and Till (1979). Palpal and leg chaetotaxy follows Evans (1963a, 1963b, 1965). The length of the second cheliceral segment was measured from its base to the apex of the fixed digit. Leg length was taken 


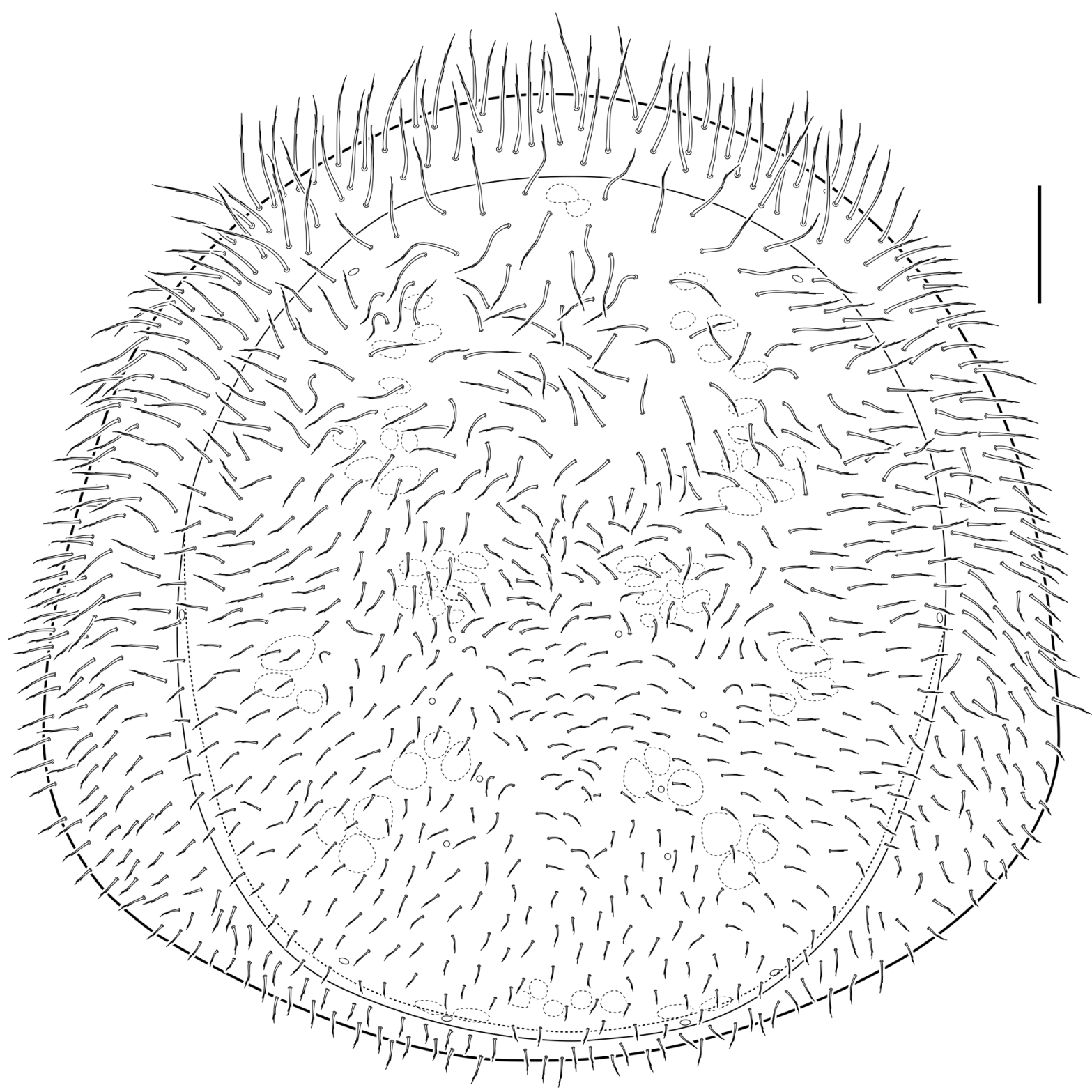

Fig. 1. Antennophorus goesswaldi Wiśniewski et Hirschmann, 1992, female: idiosoma, dorsal view. Scale bar=100 $\mu \mathrm{m}$.

from the base of the coxa to the apex of the tarsus, excluding the ambulacrum. Measurements are given in micrometres $(\mu \mathrm{m})$. The studied materials are deposited in the collection of the Department of Zoology of Odessa I.I. Mechnikov National University (Ukraine).

\section{SYSTEMATICS}

\section{Family Antennophoridae}

Diagnosis (based on Kethley 1977; Kim 2004; Lindquist et al. 2009; Gwiazdowicz 2010). Body strongly convex dorsally; holodorsal shield and soft cuticle hypertrichous, all setae of similar shape. Tritosternal laciniae free and pilose. Jugular shield entire. In female, sternal shield entire or divided longitudinally; latigynial shields free, overlapping mesogynal region; vaginal sclerites present; mesogynal shield reduced; ventrianal shield with anterior projection. In male, sternal shield paired, entire or fused with ventrianal shield. Metapodalperitrematal shields large, peritremes wide and relatively short. Hypostomal seta $h p l$ sharply modified, swollen and denticulate. Corniculi membranous, with irregularly margins and rounded apex. Epistome triangular, with median keel. Palpgenu with 7 setae, palptibia and palptarsus ventrally clearly distinguished, palptarsal apotele 2-tined. In female, chelicera chelate-dentate with minute denticles; fixit digit without excrescence or membranous process; movable digit ventrally with 


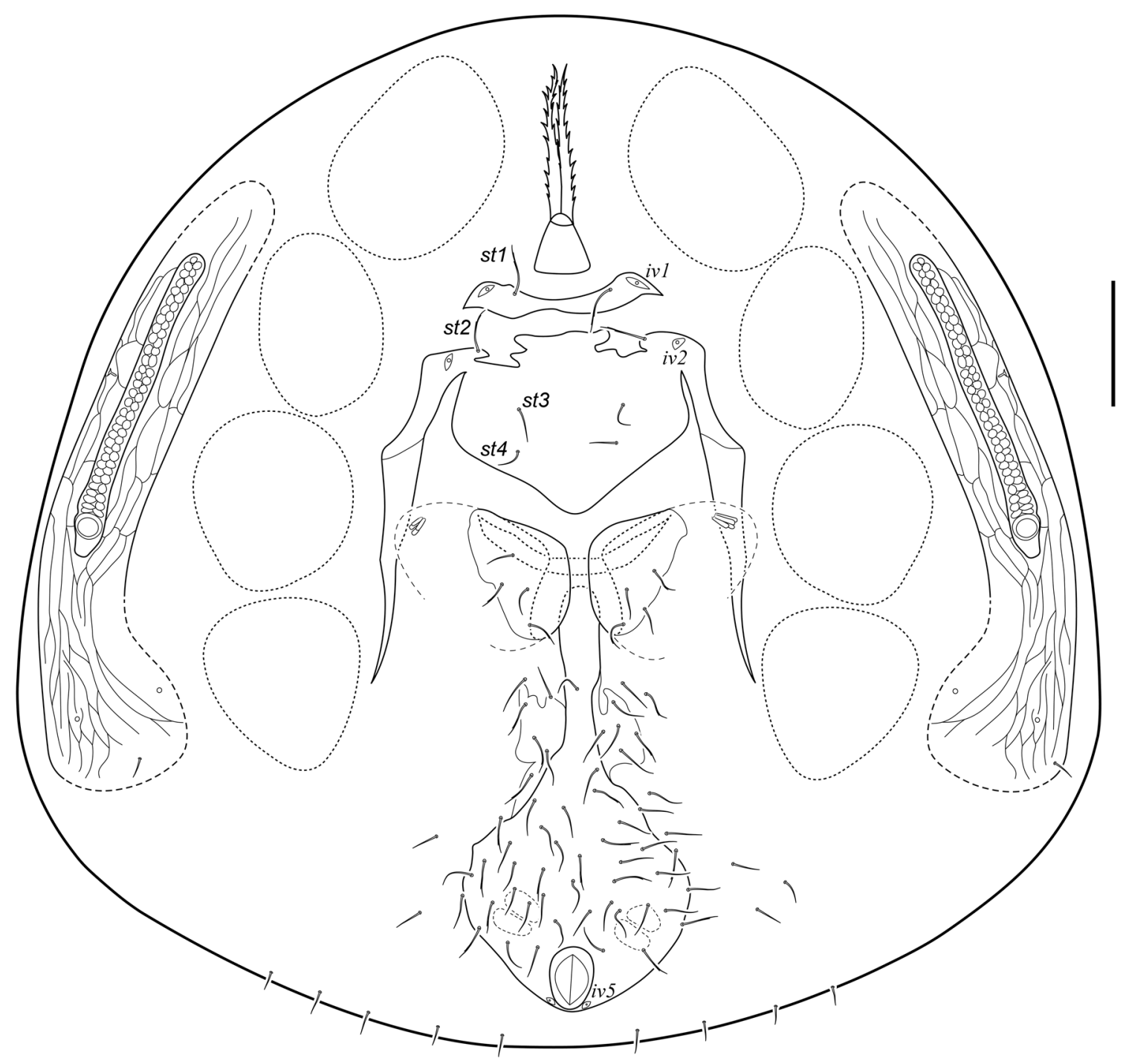

Fig. 2. Antennophorus goesswaldi Wiśniewski et Hirschmann, 1992, female: idiosoma, ventral view. Scale bar=100 $\mu$ m.

series of short setae and bunch of whip-like apically blunt projections. In male, chelicera edentate; fixit digit with several protrusions and sharp protuberance at the base of movable digit; movable digit smooth, ventrally with series of short setae and bunch of long blunt projections. Leg I hypertrophied, without ambulacrum, legs II-IV with ambulacra lacking in distinct claws.

\section{Genus Antennophorus Haller, 1877}

Type species: Antennophorus uhlmanni Haller, 1877, by monotypy

Diagnosis. As for family (monobasic).

ANTENNOPHORUS GOESSWALDI WIŚNIEWSKI ET HIRSCHMANN, 1992

Figs. 1-21
Antennophorus goesswaldi Wiśniewski et Hirschmann, 1992, p. 242, Figs. 26-30.

Diagnosis. Dorsal shield hypertrichous, with more than 600 setae. Sternal shield not divided, smooth; in female, with 3 pairs of setae, st2-st4 (rarely additional seta present asymmetrically); in male, with 4-5 pairs of setae. Ventrianal shield with numerous setae; in female, flask-like narrowing anteriad, its posterior edge rounded; in male, posterior edge weakly protruding, not widely rounded. In female, fixed cheliceral digit with about 20 small teeth, movable digit with 20-25 small teeth.

Description of female (six specimens measured; Figs. 1-20)

Idiosomal dorsum (Figs. 1, 10, 15, 16). Body subcircular in plan, strongly convex dorsally; color from yellow to brown; length of idiosoma 


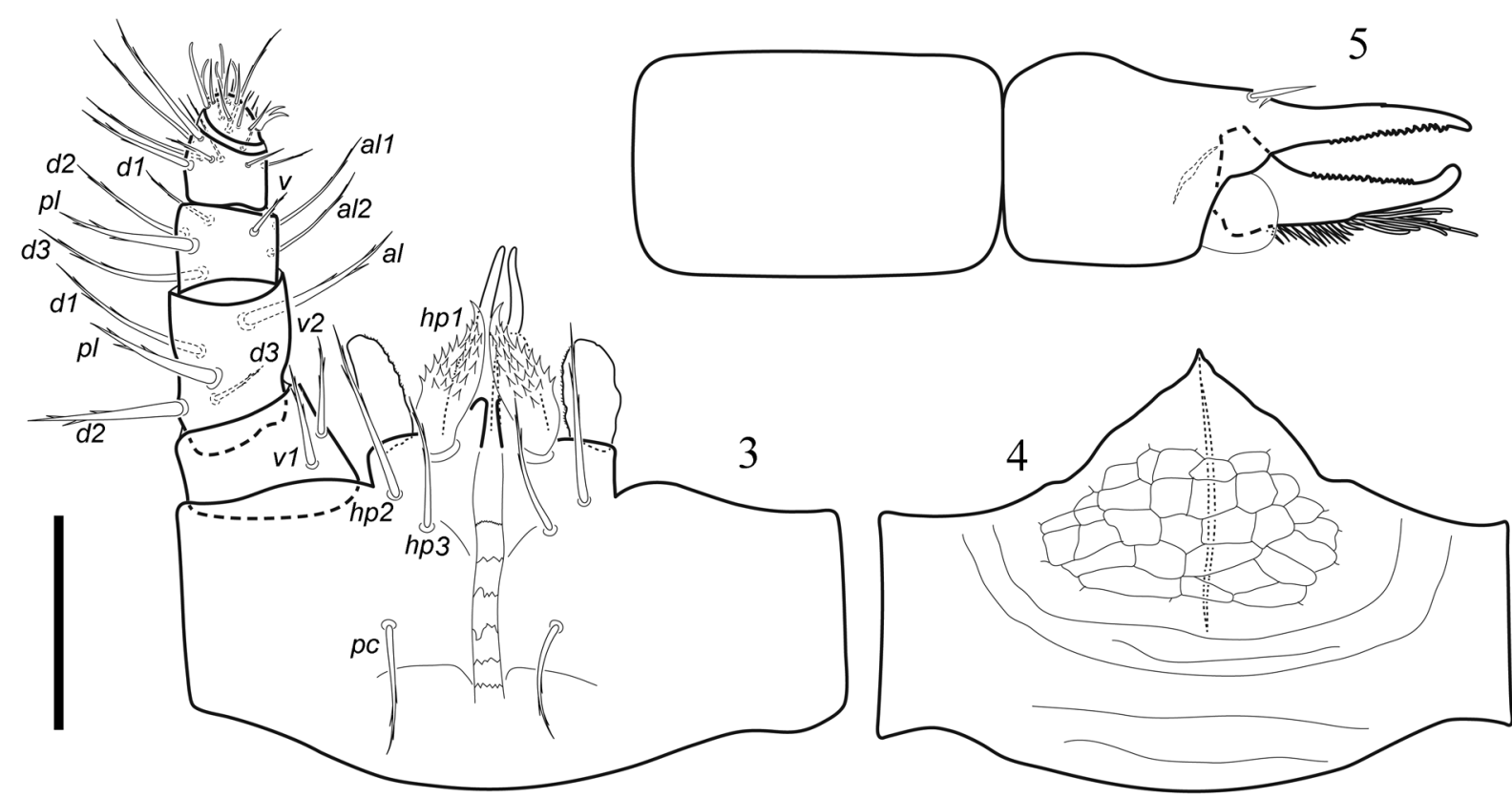

Figs. 3-5. Antennophorus goesswaldi Wiśniewski et Hirschmann, 1992, female: 3- subcapitulum and palp, ventral view; 4 - epistome; 5 - chelicera, lateral view. Scale bar $=100 \mu \mathrm{m}$.

791-837, maximum width 725-772. Dorsal shield circular in form; covering about half of dorsal surface; 716-753 long and 521-577 maximum wide; its surface slightly reticulated; with numerous (more than 600) weakly barbed setae and 8 pairs of distinguishable pore-like structures; dorsal shield setae decreasing in length from 63-84 (anterior setae) to 15-21 (posterior setae). Soft cuticle weakly striated (Fig. 16), hypertrichous; all setae weakly barbed.

Idiosomal venter (Figs. 2, 11-14, 17, 20). Tritosternum with trapezoidal base, 46-55 long, 42-53 wide at base; laciniae free, pilose, 120-126 long. Jugular shield transversal; minimal length 8-19 (at midline), maximal width 179-200; smooth; with one pair of fine barbed setae (st 1; 46-50 long) and one pair of lyrifissures (ivl). Sternal shield pentagonal, with irregular anterior margin and convex, obtuse angled posterior margin; 141-155 long; smooth; sternal shield partly fused with endopodal strip combining platelets of coxae I/II, coxae II/III and coxae III/IV; shield bearing three pairs of weakly barbed setae (st2, st 3 , st4; rarely one additional seta present) and lyrifissures $i v 2$; setae $s t 2$ located at anterolateral margins of shield, 36-40 long; setae st 3 and st 4 located in center of shield, st3 29-34 long, st4 25-29 long. Latigynial shields triangular (Figs. 2, 12), with rounded edges; smooth; their lateral margins indistinguishable; each bearing 3-6 (usually 4) weakly barbed and smooth setae (23-32 long) and group of pore-like structures. Vaginal sclerites well-developed (Fig. 17). Mesogynal shield reduced or imperceptibly merged with ventral shield. Ventrianal shield elongated, flask-like, smooth, with narrow anterior part reaching middle of latigynial shield and expanded posterior part, its posterior margin rounded, almost reaching posterior idiosomal edge (Figs. 12, 13); length 307-328, minimum width of anterior part 21-29, maximum width of posterior part 170-181; shield bearing about 40 unpaired smooth and weakly barbed setae (23-34 long); anus and lyrifissures iv 5 located near postrior shield margin; sigillae well-developed; pair of weakly sclerotized irregular platelets adjoining to middle part of ventrianal shield each with 5-9 setae. Soft cuticle behind these platelets with 1-7 pairs of smooth or weakly barbed setae (23-32 long); besides 3-5 pairs of smooth setae (17-21 long), located caudally. Metapodal-peritrematal shields large and curved, reticulated; with anterior margin weakly sclerotized and poorly visible; every shield bearing 0-2 setae (posteriorly) and 3 pairs of distinguishable pores. Peritremes wide (15-17 in middle) and relatively short (231-273), extending between posterior level of coxae III and anterior level of coxae II; with two rows of cells (about 30 in each; Fig. 20). 


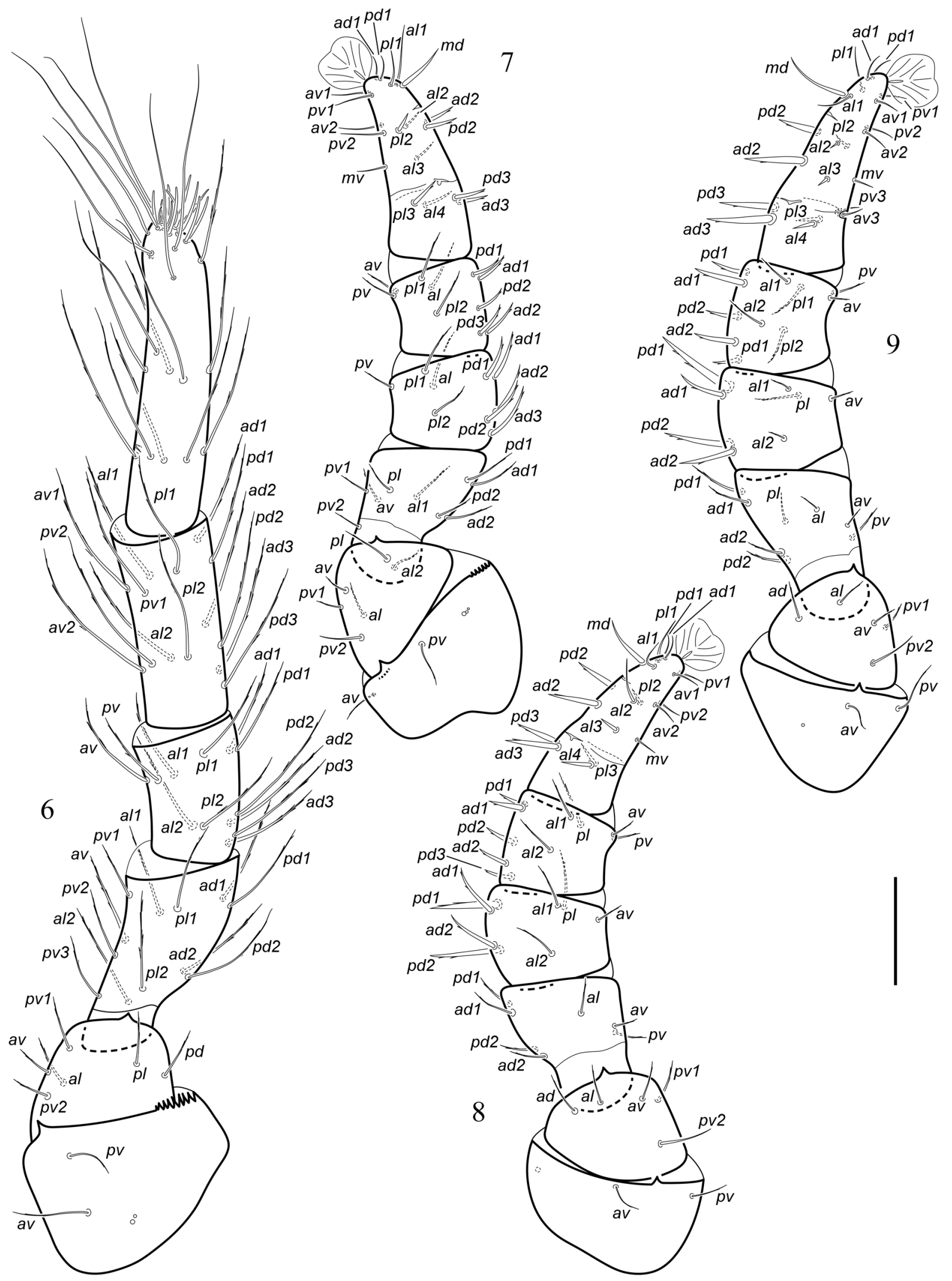

Figs. 6-9. Antennophorus goesswaldi Wiśniewski et Hirschmann, 1992, female: 9-12-legs I-IV, respectively, ventral view. Scale bar $=100 \mu \mathrm{m}$. 

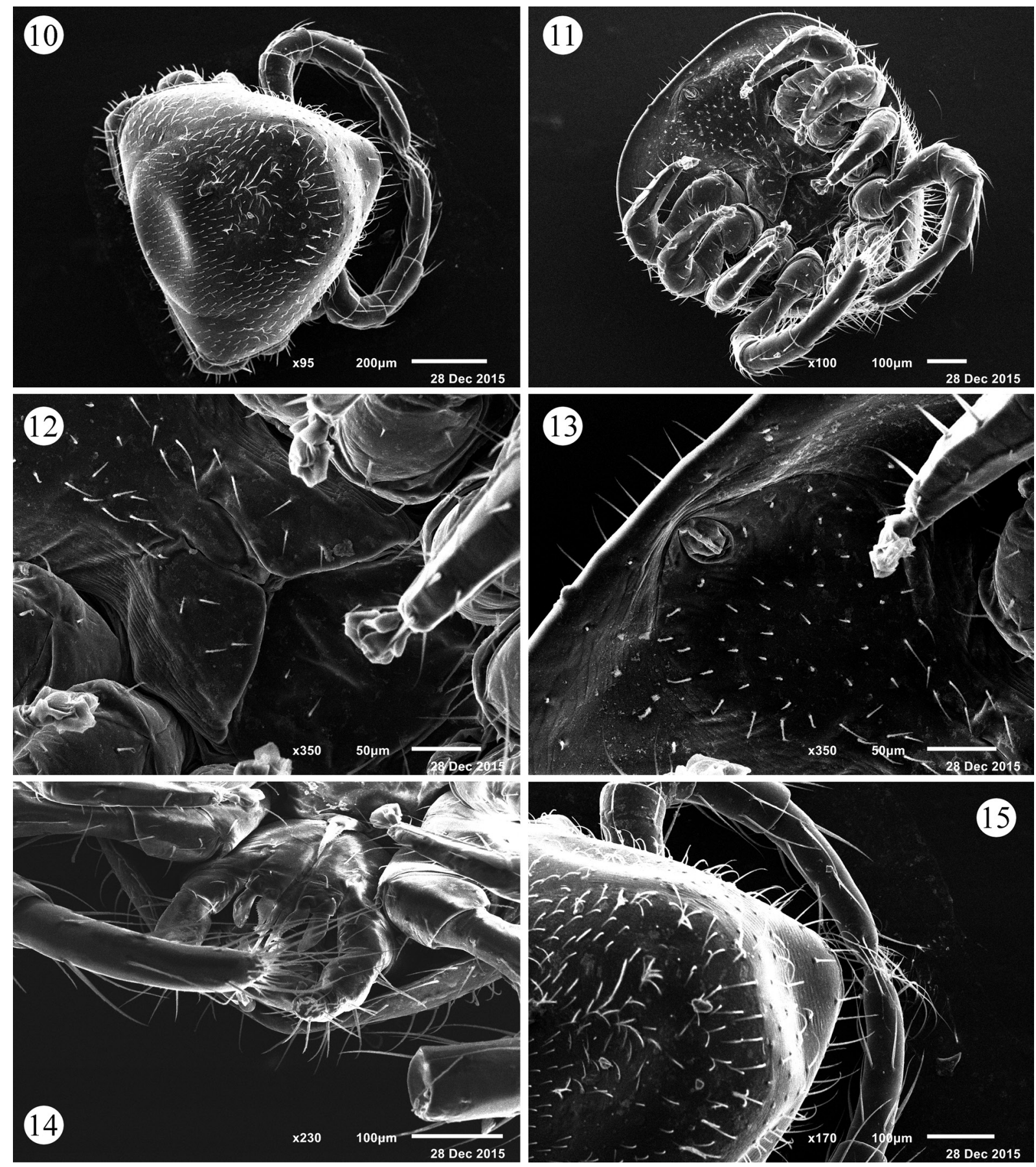

Figs. 10-15. Antennophorus goesswaldi Wiśniewski et Hirschmann, 1992, female, SEM micrographs: 10—general view, dorsally; 11-general view, ventrally; 12-sternal region; 13-anal region; 14-gnathosoma and tarsus I, anteroventral view; 15-anterior edge of the body and legs I, dorsally.

Gnathosoma (Figs. 3-5, 14, 18, 19). Subcapitulum 294-336 wide. Hypostome with 4 pairs of setae; $h p 1$ modified, club-shaped and S-shaped curved, with denticles; palpcoxal seta $(p c)$ and setae $h p 2, h p 3$ simple, weakly barbed; $p c$ 55-63, hp1 69-76, hp2 63-76, hp3 53-63, (Figs. 3, 14, 18). Deutosternum with distinguishable 6 rows; row 1 with 10-15 small denticles, rows 2-6 each with about 5 irregular, often rounded, denticles.
Corniculi poorly sclerotized; with irregularly margins and rounded apex; their inner margins weakly serrated; 53-61 long, 23-27 wide. Internal malae elongated, narrowed distally, with rounded apex, longer than corniculi and setae $h p 1$; smooth. Epistome triangular; with median keel; reticulated (Figs. 4, 19). Palp length from trochanter to tarsus tip 200-216; setal formula: 2-5-7-15-11; tarsus displaced to ventral surface of tibia; setae on tro- 

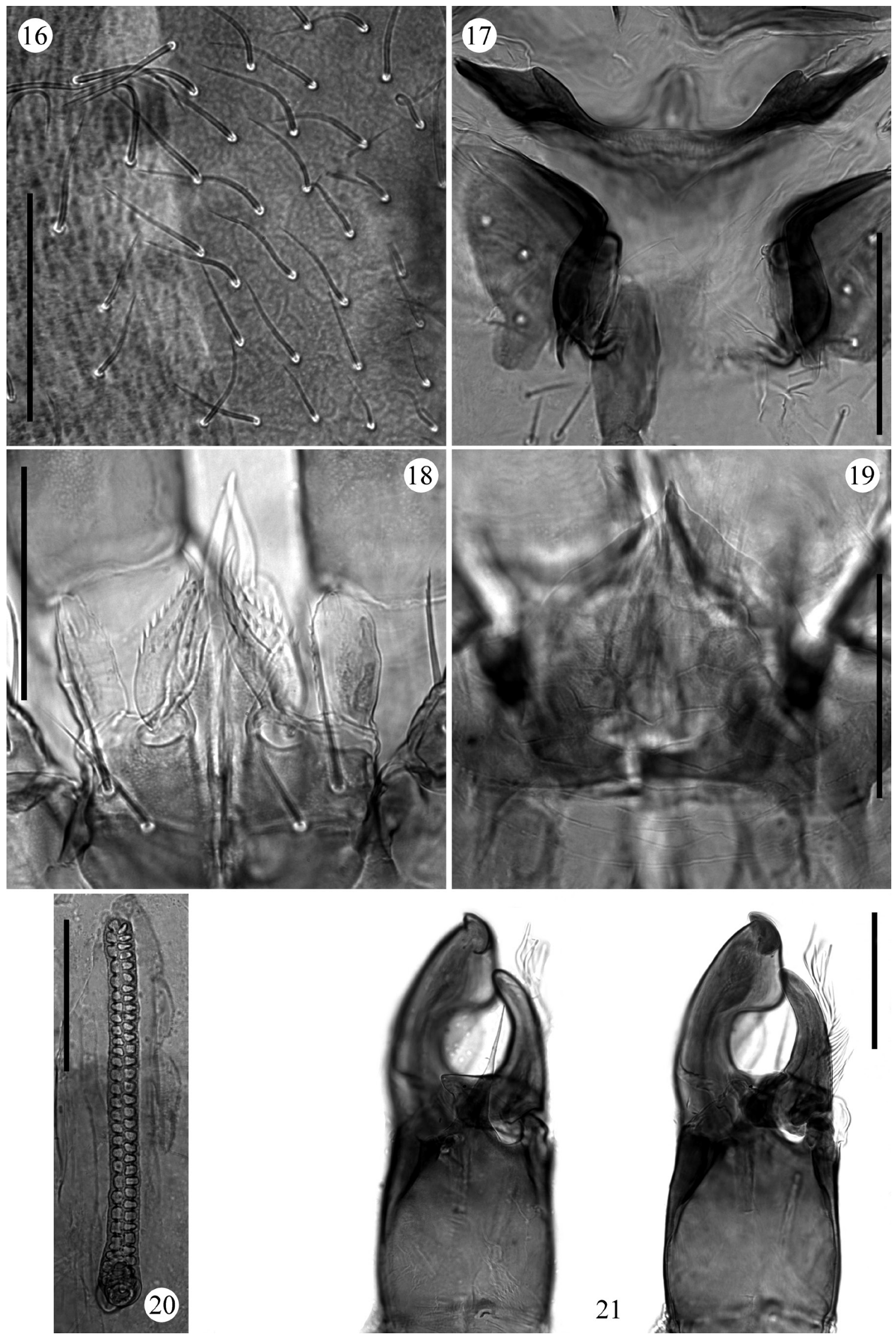

Figs. 16-21. Antennophorus goesswaldi Wiśniewski et Hirschmann, 1992, light microscopic micrographs. Female: 16-dorsal surface; 17-vaginal sclerites and latigynial elements; 18-gnathosoma, ventral view; 19- epistome; 20 - peritrema. Male: 21 — chelicera, with different depth of field. Scale bars $=100 \mu \mathrm{m}$. 
chanter, femur, genu and tibia finely barbed; palptarsal apotele 2-tined (Fig. 3). Chelicerae chelatedentate; second cheliceral segment length 210-225, movable digit length 109-113 (Fig. 5). Fixed digit with about 20 small denticles; dorsal lyrifissure, antiaxial lyrifissure and dorsal seta distinct. Movable digit with 20-25 small denticles; ventrally with series of short setae and bunch of whip-like, apically blunt projections.

Legs (Figs. 6-9, 14, 15). Lengths: I-9211025, II-605-632, III-642-679, IV-679-744.

Leg I without ambulacrum; legs II-IV with ambulacra, claws not distinct. Leg chaetotactic formulae: leg I: coxa $2(00 / 10 / 10)$, trochanter $6\left(\begin{array}{llll}1 & 0 / 1 & 1 / 2\end{array}\right.$ 1), femur $12(22 / 12 / 32)$, genu $12(23 / 13 / 12)$, tibia 14 (2 3/2 3/2 2); leg II: coxa $2\left(\begin{array}{llll}0 & 0 / 1 & 0 / 1 & 0\end{array}\right)$, trochanter $5(10 / 10 / 21)$, femur $10(22 / 12 / 21)$, genu 9 (1 3/0 2/1 2), tibia $10(12 / 13 / 12)$, tarsus 19 (4 3/2 1/1 3/2 3); leg III: coxa 2 (0 0/1 0/1 0), trochanter $5\left(\begin{array}{llll}1 & 1 / 1 & 0 / 2 & 0)\end{array}\right)$, femur $7\left(\begin{array}{llll}1 & 2 / 1 & 2 / 1 & 0\end{array}\right)$, genu $8(22 / 12 / 01)$, tibia $10(22 / 13 / 11)$, tarsus 19 (4 3/2 1/1 3/2 3); leg IV: coxa $2(0$ 0/1 0/1 0), trochanter $5\left(\begin{array}{llll}1 & 1 / 1 & 0 / 2 & 0\end{array}\right)$, femur $8\left(\begin{array}{llll}1 & 2 / 1 & 2 / 1 & 1\end{array}\right)$, genu $8(22 / 12 / 01)$, tibia $11(22 / 13 / 12)$, tarsus $21(43 / 3$ 1/1 3/3 3). All coxae and tarsi with pores. Setae $p v 2$ on trochanters II-IV flagellate and smooth, other setae on coxae, trochanters, femora, genua and tibiae weakly barbed; setae of $a d$ - and $p d$-series on genua and tibiae II-IV thickened. Setae on tarsus I rather long, weakly barbed (located proximally) or smooth (located distally; Figs. $6,14,15)$. On tarsi II-IV, setae $a d 1, p d 1$ and all ventral setae simple and smooth; setae $a d 2, a d 3$, $p d 2, p d 3$ thickened, barbed; seta $m d$ thickened at base, smooth; setae all and pll flagellate, smooth; shape of setae al2 and $p l 2$ variable (flagellate or weakly thickened); setae al3 and al4 weakly thickened, hardly barbed or smooth; setae $p l 3$ thickened, weakly barbed (Figs. 7-9).

Material examined. Ca. 100 females and males, Crimea, Yalta City Municipality, vicinity of

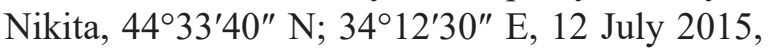
Nikitskaya Mt., mountain steppe, on workers of Lasius flavus Fabricius, 1781 (Hymenoptera: Formicidae) from the anthill, leg. A.A. Khaustov.

Remarks. Both sexes of Antennophorus goesswaldi are characterized by an undivided sternal shield. This trait they share with adults of $A$. boveni, female of $A$ foreli (male is not known), male of $A$. pavani (female is not known), and male of $A$. pubescens (female has a divided sternal shield). The female of $A$. goesswaldi differs from the female of $A$. boveni by the setae $s t 2$ located on sternal shield (on soft cuticle in A. boveni), the male of A. goesswaldi also differs from male of $A$. boveni by having a smooth sternal shield (reticulate-foveate in $A$. boveni). The female of $A$. goesswaldi differs from the female $A$. foreli by the number of setae on dorsal shield (>600 in A. goesswaldi vs ca. 100 in A. foreli) and ventrianal shield (ca. 40 setae in $A$. goesswaldi vs ca. 8 in $A$. foreli). The male of $A$. goesswaldi differs from the male of $A$. pavani by the number of setae on sternal shield (ca. 10 in A. goesswaldi vs ca. 20 in A. pavani) and by the shape of the posterior edge of ventrianal shield (weakly protruding in A. goesswaldi, rounded in A. pavani).

Kethley (1977) noted that the Antennophorus spp. are lacking seta $a d 3$ on genu II and seta $p l 2$ on tibia IV, but both setae are present in the studied specimens $A$. goesswaldi.

Only adults of Antennophorus goesswaldi were found on ants, and about half of females were gravid with 1-2 eggs inside.

\section{ACKNOWLEDGEMENTS}

The authors thank Alexander A. Khaustov (Tyumen State University, Tyumen, Russia) for providing material for study, as well as for his valuable comments on the manuscript, and the two anonymous reviewers for their suggestions for the improvement of this paper.

\section{REFERENCES}

Berlese, A. 1904. Illustrazione iconografica degli Acari mirmecofili. Redia, 1: 299-474.

Evans, G.O. 1963a. Observations on the chaetotaxy of the legs in the free-living Gamasina (Acari: Mesostigmata). Bulletin of the British Museum (Natural History), Zoology, 10: 277-303. https://doi.org/10. 5962/bhl.part.20528

Evans, G.O. 1963b. Some observations on the chaetotaxy of the pedipalps in the Mesostigmata (Acari). Annals and Magazine of Natural History, Series 13, 6: 513-527. http://dx.doi.org/10.1080/0022293 6308651393

Evans, G.O. 1965. The ontogenetic development of the chaetotaxy of the tarsi of legs II-IV in the Antennophorina (Acari: Mesostigmata). Annals and Magazine of Natural History, Series 13, 8: 81-83. https://doi.org/10.1080/00222936508651543

Evans, G.O. and Till, W.M. 1979. Mesostigmatic mites of Britain and Ireland (Chelicerata: Acari-Parasitiformes). An introduction to their external morphology and classification. Transactions of the Zoological Society of London, 35: 139-270. http:// dx.doi.org/10.1111/j.1096-3642.1979.tb00059.x 
Franks, N.R., Healy, K.J. and Byrom, L. 1991. Studies on the relationship between the ant ectoparasite Antennophorus grandis (Acarina: Antennophoridae) and its host Lasius flavus (Hymenoptera: Formicidae). Journal of Zoology, London, 225: 59-70.

Gwiazdowicz, D.J. 2010. Sejoidea, Antennophoroidea, Celaenopsoidea, Microgynioidea (Acari, Mesostigmata) of Poland. Bogucki Wydawnictwo Naukowe, Poznań, 142 pp.

Haller, G. 1877. Antennophorus uhlmanni. Ein neuer Gamaside. Archiv für Naturgeschichte, 43: 57-62.

Janet, M.Ch. 1897. On the relations of Antennophorus uhlmanni, Haller, to Lasius mixtus, Nyl. Annals and Magazine of Natural History, 19: 620-623.

Karawaiew, W. 1905a. Antennophorus uhlmanni Hall. und seine biologischen Beziehungen zu Lasius fuliginosus und anderen Ameisen. Mémoires de la Société des Naturalistes de Kiev, 19: 193-241. [In Russian with Deutsch summary]

Karawaiew, W. 1905b. Versuche über die internationalen Beziehungen einiger Antennophorus-arten, nebst einigen systematischen Bemerkungen. Zeitschrift für wissenschaftliche Insektenbiologie, 1: 485-493.

Kethley, J.B. 1977. A review of the higher categories of Trigynaspida (Acari: Parasitiformes). International Journal of Acarology, 3: 129-149.

Khaustov, A.A. 1997. [Mites of supercohort Trigynaspida (Parasitiformes, Celaenopsidae, Cercomegistidae) associated with bark beetles (Coleoptera, Scolytidae) of the Crimea]. Bulletin of the State Nikita Botanical Gardens, 78: 63-66. [In Russian]

Khaustov, A.A. 1999. A new species of the genus Schizocyrtillus (Acarina: Mesostigmata: Celaenopsidae) from Crimea. Acarina, 7: 107-109.
Kim, Ch.-M. 2004. Trigynaspida (Acari: Mesostigmata): new diagnosis, classification, and phylogeny. Acarologia, 44: 157-194.

Krantz, G.W. 1970. A Manual of Acarology. Oregon State University Bookstores, Corvallis, 335 pp.

Lindquist, E.E., Walter, D.E. and Krantz, G.W. 2009. Chapter twelve. Order Mesostigmata. In: G.W. Krantz and D.E. Walter (Eds.). A Manual of Acarology. $3^{\text {rd }}$ edition. Texas Tech University Press, Lubbock, pp. 124-232.

Trach, V.A. 2013. On the morphology, biology and distribution of Lobogynioides andreinii (Acari, Mesostigmata, Diplogyniidae). Entomological Review, 93: 105-112. http://dx.doi.org/10.1134/ s0013873813010144

Trach, V.A. and Khaustov, A.A. 2017. Redescription of adults and description of juvenile stages of bark beetle-associated mite Cercoleipus kuznetsovi Khaustov, 1997 (Acari: Mesostigmata: Cercomegistidae). Systematic \& Applied Acarology, 22: 1733-1747. http://doi.org/10.11158/saa.22. 10.13

Wasmann, E. 1899. Weitere Nachträge zum Verzeichnis der Ameisengäste von Holländisch Limburg. Tijdschrift voor Entomologie, 42: 158-171.

Wasmann, E. 1902. Zur Kenntnis der myrmecophilen Antennophorus und anderer auf Ameisen und Termiten reitender Acarinen. Zoologischer Anzeiger, 25: 66-76.

Wheeler, W.M. 1910. Two new myrmecophilous mites of the genus Antennophorus. Psyche, 17: 1-6.

Wiśniewski, J. and Hirschmann, W. 1992. Gangsystematische Studie von 3 neuen Antennophorusarten aus Polen (Mesostigmata, Antennophorina). Acarologia, 33: 233-244. 